Pawłowski, M. (2018). Financing the solar energy market through the use of securitization - the case of the United States. Copernican Journal of Finance \& Accounting, 7(2), 63-76. http://dx.doi. org/10.12775/CJFA.2018.009

Maciej PaWrowski*

The University of Szczecin

\title{
FINANCING THE SOLAR ENERGY MARKET THROUGH THE USE OF SECURITIZATION - THE CASE OF THE UNITED STATES
}

Keywords: solar energy, finances, renewable energy sources, securitization, financial market.

\section{J E L Classification: G1, G23, P28, Q4.}

\begin{abstract}
This article corresponds with the research on the implementation of general sustainable development ideas. Moreover, it addresses the issue of using securitization in financing the solar energy market in the U.S. The aim of the research is to identify the essential characteristics of lease securitization of photovoltaic installations, as well as illustrate the current market development of these instruments. The paper discusses theoretical framework of securitization, identifies essential characteristics of the photovoltaic installation market in the context of its potential regarding the use of the securitization process, and presents the state of the securitization market in the discussed area. The characteristics presented in the article are based on the examples of the United States economy - the birthplace of lease securitization of photovoltaic installations, as well as the only state, where the analysed instrument finds practical application, so far.
\end{abstract}

Date of submission: August 31, 2018; date of acceptance: October 3, 2018.

* Contact information: maciej.pawlowski@wzieu.pl, Department of Finance and Banking, Faculty of Management and Economics of Services, The University of Szczecin, Cukrowa 8, 71-004 Szczecin, Poland, phone: +48 9144431 87; ORCID ID: https://orcid. org/0000-0002-1885-1722. 


\section{INTRODUCTION}

There is no doubt that electrical energy is one of the most important factors behind the economic and civilization development of contemporary world economies. The dynamic processes of technical progress and increased innovation, which have been observed in the global economic system, as well as the growing world population directly translate into an increase in demand for electricity, and, consequently, lead to a greater scale of its production. At the same time, the necessity to implement a sustainable development concept is getting more and more prominent, which, in the context of the undertaken issue, can be understood as a certain compromise between maintaining the usefulness and quality of natural resources and satisfying the global economy's demand for electricity. As a consequence, the market of energy that comes from renewable energy sources is becoming increasingly important not only in the consciousness of modern societies, but also in the attitudes and actions of the broadly defined participants of economic life.

\section{THE RESEARCH METHODOLOGY}

\section{AND THE COURSE OF THE RESEARCH PROCESS}

This article falls into the mainstream part of the interest in instruments that support the implementation of sustainable development objectives, and aims at identification of essential characteristics of lease securitization of photovoltaic installations, as well as illustration of the current market development of these instruments. The paper discusses theoretical framework of securitization, identifies essential characteristics of the photovoltaic installation market in the context of its potential regarding the use of the securitization process, and presents the state of the securitization market in the discussed area. The characteristics presented in the article are based on the examples of the United States economy - the birthplace of lease securitization of photovoltaic installations, as well as the only state, where the analysed instrument finds practical application, so far ${ }^{1}$.

1 This study takes the form of a review article that summarizes the current state of knowledge and experience in the field of securitization of leasing photovoltaic installations as presented on the example of the U.S. economy. Focusing considerations on the example of the U.S. is deliberate and justified by two different prerequisites. 


\section{THEORETICAL FRAMEWORK OF SECURITIZATION PROCESS}

Securitization is defined as a process during which diversified pool of financial assets, together with cash flow they generated, are isolated from initiator's balance (company, financial institution, government or local government unit), secured by means of internal and external methods, and made legally independent in the so-called special purpose vehicle (SPV), which then refinances the purchased asset pool through the issuance of debt securities in domestic and (or) international capital markets (Reksa, 2007, pp. 5-6). Executing securitization transaction by the initiator, and thus financing business activity by means of this mechanism, is therefore conditioned by the category of assets in the initiator's balance sheet. It is considered that anything that has value and generates regular financial flows may be the subject of securitization (Bartos, 2006, p. 286), whereas assets subject to this process should be characterized by the certainty of future issuances and their full predictability as to the date and size. In order to strengthen securitization process, mainly in the scope of management of claims of investors who acquire securitized asset-backed debt securities, it is required that (Waszkiewicz, 2011, pp. 45-47):

- the process of standardizing securitized assets in the scope of their type is carried out, choosing relatively similar assets without combining their different categories;

- long-term assets, whose liquidation period is longer than 1 year, are subject to securitization;

- there is substantial likelihood that selected assets are satisfied by the debtors;

Firstly, as it was already mentioned, the pioneering securitization transactions used in financing of the solar energy market have been carried out in the U.S., and therefore the empirical material will have relatively long history (compared to other countries, where the securitization mechanism is used in financing of the renewable energy market). Secondly, focusing solely on the U.S. economy and omitting international comparisons stems from the fact that the securitization of leasing of photovoltaic installations is not practical in other economic systems. It is true that there exist press reports regarding the use of securitization in the financing of the Chinese solar market, however, this model of integrated funding is based on bank loans financing photovoltaic installations and not, as in the case of the U.S. economy, direct lease of photovoltaic installations. The completely different nature of securitization models means that comparing figures without identifying different financing structures would be unjustified. 
- a bundle of securitized assets is diversified and big enough (both in terms of value and volume) to minimise risk associated with these assets ${ }^{2}$.

In their essence, securitization transactions go well beyond financing of activities carried out by the initiator of such process. The literature on the subject indicates that decisions on the use of securitization may be justified because of:

- need to change the company's asset structure and diversified its sources of financing;

- possibility to reduce the cost of capital financing the entity's activity;

- necessity to manage company's risk;

- seeking to obtain a higher position in ratings;

- necessity to meet regulatory requirements (especially in the scope of capital adequacy);

- managing tax liabilities ${ }^{3}$ (cf. Fabozzi \& Kothari, 2008, p. 13 et seq.; Kothari, 2006, p. 97 et seq.; Davidson, Sanders, Wolff \& Ching, 2003, p. 15 et seq.).

The multidimensional nature of benefits, which result from executing securitization transactions, is a derivative of this process foundation - isolation and transfer of assets to Special Purpose Vehicle (SPV). The preferences of initiator of securitization, which regard the expected benefits, are difficult to be assessed, as in principle, along with the transfer of assets, each of the above aspects occurs jointly, although to a different extent. It is thus concluded that the basic premise for securitization is a financial aspect expressed in converting low-level liquid assets into cash that supports the process initiator's activities.

\section{ASSET SECURIZATION AND THE FINANCIAL CRISIS - TO SECURITIZE OR NOT?}

Asset securization constitutes one of the most complicated funding techniques and an important part of the modern financial engineering instrumentarium

${ }^{2}$ It is important to maintain the principle stating that a small number of debtors should not be responsible for the disproportionately high value of liabilities, while diversification of debtors should occur in the geographical scope and within the nature of their activity - for example, an originally obliged group should not consist only of entrepreneurs operating in the same area and bearing the same economic risk (Raczkowska, 2001, p. 18).

3 The use of securitization in the process of tax optimization is described by (Półtorak, 2017). 
(Półtorak, 2017, p. 78). This particular type of innovation in the field of capital absorption was created in the American financial system in the 1970s (Kothari, 2006, p. 112), in the period of increased demand for condominium units, the purchase of which was financed with a significant share of long-term mortgage loans. In order to face the growing demand for mortgage lending, it became necessary to refinance existing debt securities, thus encouraging financial institutions to look for ways to expand and diversify the sources of financing of rapidly progressing crediting lending (Buchanan, 2017, pp. 12-13; Półtorak, 2005, p. 123). On this basis, a financial concept based on portfolios of granted mortgage loans was created. The concept, by its very nature, focused on the issue of debt securities backed by a collection of bank liabilities, which constituted a source of ongoing servicing of issued securities, as well as their future purchase. This financial funding process carried out in 1970 by the Government National Mortgage Association is considered the first securitization process in history (Deku \& Kara, 2017, p. 59).

The success of a mortgage portfolio-based transaction created the basis for expanding the portfolio of assets that were the subject of the securitization. The foundations of the analysed mechanism included, among others, leasing liabilities, receivables deriving from car loans, receivables from credit cards, student loans or proprietary copyrights. The progressing diversification of assets subject to securitization, the increasing diversification of instruments resulting from this process, as well as the high degree of complexity and the lack of transparency in transactions had led to a situation, where securitization started to be regarded the source of the financial crisis of the 21st century (Buszko \& Krupa, 2016, p. 76; Waszkiewicz, 2011, p. 13). However, this view was not justified in the statistics relating the insolvency risk diagnosed for the debt securities market. The estimates of the rating agency Stadard \& Poor's indicate that the credit risk concerned only $7.7 \%$ of the value of securitization transactions conducted on the basis of the U.S. financial system, being a little over than the default rate of issuers of classical corporate bonds (6.34\%) (Blommestein, Keshinler \& Lucas, 2011, p. 3).

Certainly, securitization is strongly related to the rationale of the recent financial crisis and has contributed to the escalation of the recession of financial markets. Nevertheless, after some time and many thorough analyses and evaluations, securitization, as a funding method, has been recognized as a solution that enables effective risk management; ensures a direct access to the capital markets based on the assets of the entity initiating this process; is used to 
manage the structure of assets and sources of their financing, and thus allows collection of funds in a less costly manner than in the case of traditional debt instruments (bonds or short-term debt securities).The financial crisis only revealed the weaknesses of the current securitization model, which concern four main areas: (1) loans with increased credit risk (including subprime loans) should not be the subject of securitization; (2) bank loans granted with the intention of their further resale under the securitization process entail the risk of fraud (moral hazard); (3) a conflict of interest, which is consistent with principal-agent problem, can be observed in the securitization structure ${ }^{4}$ (4) securitization market participants attach excessive importance to mathematical models and related ratings, regardless of the other elements that make up the complexity of the securitization mechanism (Schwarcz, 2010, p. 595). In this regard, the correlation between securitization and the 21th century financial crisis should be perceived in terms of the weakness of financial architecture, especially norms and prudential regulations (Mrzygłód, 2012, p. 31), which accompany the conducted transactions.

Graph 1. Value of the securitization market in the United States, taking into account the value of new issues in 1985-2017 (in billion USD)

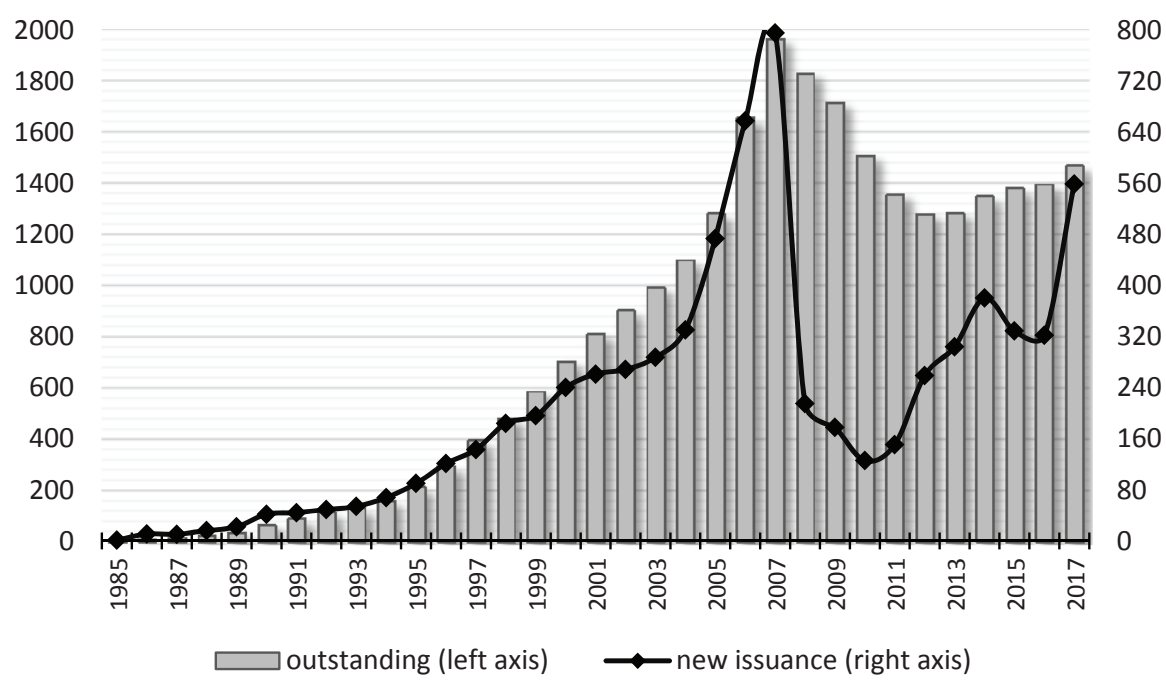

S o u r c e : own work based on: www2.

4 Cf. (Paligorova, 2009). 
Awareness of the benefits brought by securitization and severe verification of the imperfections of the regulatory environment of this process is reflected in the activities aimed at improving the efficiency and security of transactions. The fundamental conclusion that arises from the recent financial crisis is not to stop applying securitization, but to strengthen the regulatory framework and the security of these transactions. Consequently, securitization understood as a mechanism of capital absorption still has a practical application (graph 1), and, more importantly, it shows development trends, gradually including more and more categories of assets. One of them is solar energy (more precisely - financial flows generated by photovoltaic installations) that is the subject of this study.

\section{LEASING OF PHOTOVOLTAIC INSTALLATIONS - A NEW CLASS OF ASSETS SUBJECT TO SECURITIZATION PROCESS}

The concept of using securitization in financing the solar energy market stems from the American economic system and politics regarding renewable energy sources. Between 2005-2015, the American market of energy obtained from solar radiation had been growing extremely dynamically - solar energy production had increased more than fifty times, and the number of installed photovoltaic installations recorded a 77-fold increase (0'Sullivan \& Warren, 2016, p. 4). The dynamics of these processes resulted in a situation where in 2015 the U.S. economy was responsible for $15 \%$ of global solar production, as compared to the 7\% share achieved in 2011 (Jacoby, 2013, pp. 205-206). The factors stimulating the development of the American solar energy market include, first and foremost, federal tax preferences (cf. Comello, Reichelstein, 2015) and falling costs of photovoltaic installations. It is estimated that in 2010 the average cost of a single photovoltaic installation amounted to USD 7.24 per unit of energy produced (1 Watt DC), whereas in 2017, the cost was USD $2.80^{5}$ (Fu, Feldman, Margolis, Woodhouse \& Ardani, 2017, p. VI).

A consequence of the development of the solar energy market is an increased demand among potential users for funding photovoltaic installations.

5 The indicated costs regard photovoltaic installations in residential property sector. The cost statistics for photovoltaic installations for other user categories is presented in: (Fu, Feldman, Margolis, Woodhouse \& Ardani, 2017, p. VI). It should be added that successive decrease in unit costs of systems used to acquire solar energy can be observed in every segment of customers who bought photovoltaic installations. 
Under market economy conditions that are the subject of this article, two basic forms of ownership of solar systems have been developed, namely installations which constitute an object subject to ownership rights and installations which are objects of use (without transfer of ownership rights). Therefore, in the statistics regarding the analysed market (e.g. studies periodically published by GTMResearch (www1) there can be observed a dichotomous and aggregated division of funding sources of photovoltaic installations into those that require a transfer of ownership rights of a given system to its user (own funds of users, credits and loans), and those which give only the right to use and derive benefits from the installation (leasing). The way in which data is presented does not diminish its cognitive value, as the leasing of solar installations is at the heart of the process of solar energy securitization.

Graph 2. The ownership structure of photovoltaic installations in the USA in 2010-2015

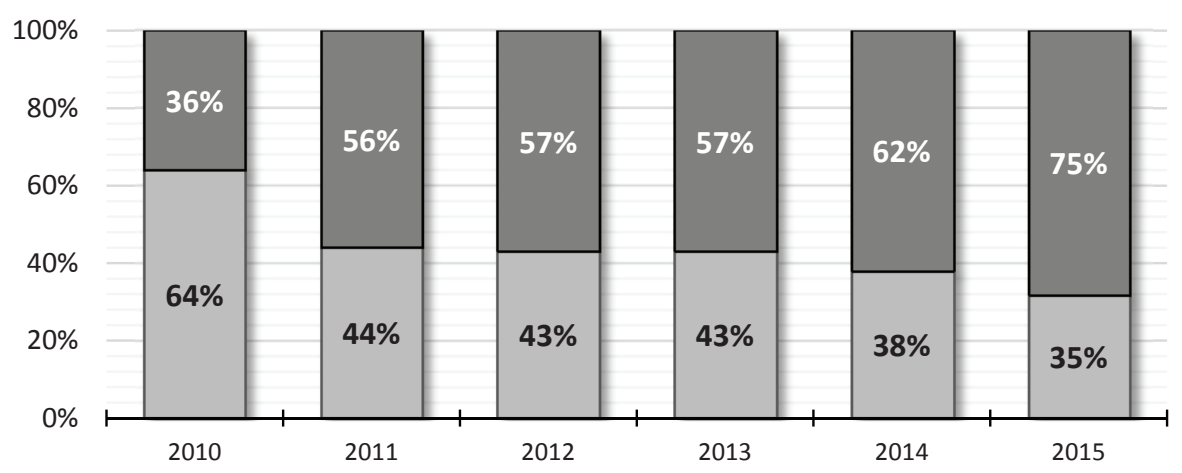

$\square$ installations with the transfer of the ownership $\square$ installations with the right of use

S o u r c e : own work based on: www1.

The ownership structure of photovoltaic installations (graph 2) illustrates this market potential as an area where securitization mechanism can be applied. From 2010 to 2015, there could be observed a successive increase in the importance of leasing in financing solutions for obtaining solar energy, which, together with high growth of the discussed market, justify the need of operators to seek sources of capital, while acting as financial intermediaries. Marinating this development trend in the solar energy market requires an adequate 
capital basis that allows provision of both photovoltaic installations and funding in the form of a lease ${ }^{6}$. In 2013 alone, provision of solutions to the U.S economy, which was aimed at achieving $3.3 \mathrm{GW}$ of solar energy, cost market operators USD 12 billion (Alafita \& Pearce, 2014, p. 489).

Under the U.S. financial system conditions, the increasing capital needs of operators on the photovoltaic installation market are met under the securitization transactions. The activities of these entities (apart from providing solar energy systems) are based on concluding long-term leasing agreements, which generate financial assets as well as bring a steady and diversified cash flow. The characteristics of this part of the assets of entities that provide solar systems reflect the desirable features of the collateral assets used in the securitization process.

Graph 3. Value of the lease securitization market of photovoltaic installation in the U.S., taking into account the value of new issues in 2013-2017 (in billion USD)

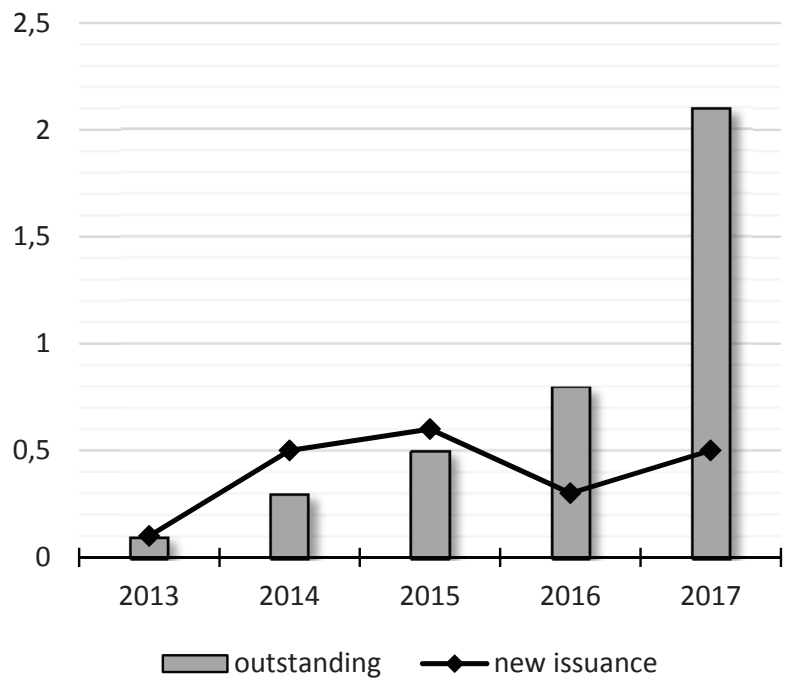

S o u r c e : own work based on: www2.

${ }^{6}$ Photovoltaic installation leasing in essence does not deviate from model objectives of this financing instrument. The user of the installations signs a new long-term agreement (usually for 20 years), based on which they acquire a right to obtain benefits from a system that converts solar radiation into electrical energy, and thus commit themselves to pay interim payments (rent) (Jacoby, 2013, p. 213). 
The potential of securitization in the financing of solar energy market was initially recognized in 2013, when, for the first time in history, instruments of this class were issued (graph 3). Over the five-year period of operation, this market was gradually increasing its value, and experienced an impressive sales growth - 2014/2013 - 300\%; 2015/2014 - 167\%; 2016/2015 - 160\%; $2017 / 2016-263 \%$. The reasons why operators from the solar energy market are more and more interested in financing through securitization mechanism stem from the above-mentioned need to release capital frozen in financial assets (leasing agreements) in order to use it to finance subsequent photovoltaic installations. It is also worth mentioning that the market of solar energy securitization, despite high sales growth, is quite small when compared to the American market of financial instrument securitization. In 2013, solar energy securitization accounted for $0.01 \%$ of the total value of securitization transactions carried out in the U.S., and in $2017-0.14 \%$.

\section{THE PAST EXPERIENCES REGARDING LEASE SECURITIZATION OF PHOTOVOLTAIC INSTALLATIONS IN THE U.S.}

A short period of securitization market operation based on leasing of photovoltaic installations results in the lack of aggregate figures and in-depth analyses of this market. The published information is fragmentary and comes from information published as part of relations between investors. Therefore, it presents selective statistics that characterize securitization programmes carried out by entities that use this mechanism to finance their business activities. One of the few works attempting to organize the current state of the lease securitization market of photovoltaic systems is presented by O'Sullivan and Warren (2016). O'Sullivan and Warren evaluate the market based on the relation between two parameters: (1) power of photovoltaic systems, which are financed through leasing subject to securitization, and (2) total power of installed photovoltaic systems. The estimates show that from $5.6 \mathrm{GW}$ of the total power of installed photovoltaic systems, the securitization process covered systems representing $0.438 \mathrm{GW}$ of power (figures presented in the aggregated manner at the end of the first quarter of 2016). It therefore appears that the securitization process covered $7.8 \%$ of the provided photovoltaic systems, which are financed through leasing (O'Sullivan \& Warren, 2016, p. 17). Such a high share of securitization in financing of photovoltaic installations is justified by the structure of operators performing activities in the U.S. solar energy market. This 
market is oligopolistic and comprises three companies - SolarCity, Sunrun and Vivint Solar, which together have $73 \%$ share in the photovoltaic installation market (respectively: 40\%, 18\% and 15\% share of the market; data referring to the end of 2016) (www1). This is important since the entity that is the most active in terms of performing securitization transactions concerning leasing of photovoltaic installations is SolarCity.

Table 1. Characteristics of selected securitization transactions for leasing photovoltaic installations in the USA in 2013-2016

\begin{tabular}{|c|c|c|c|c|c|c|}
\hline \multirow{2}{*}{$\begin{array}{c}\begin{array}{c}\text { Initiator } \\
\text { of securitization process }\end{array} \\
\text { Series }\end{array}$} & \multicolumn{5}{|c|}{ SolarCity } & \multirow{2}{*}{$\begin{array}{l}\text { Sunrun } \\
\text { Callisto }\end{array}$} \\
\hline & $\begin{array}{c}\text { LMC } \\
\text { Series I }\end{array}$ & $\begin{array}{c}\text { LMC } \\
\text { Series II }\end{array}$ & $\begin{array}{c}\text { LMC } \\
\text { Series III }\end{array}$ & $\begin{array}{c}\text { LMC } \\
\text { Series IV }\end{array}$ & $\begin{array}{c}\text { LMC } \\
\text { Series V }\end{array}$ & \\
\hline Closing Date & $\begin{array}{c}\text { November } \\
2013\end{array}$ & $\begin{array}{l}\text { April } \\
2014\end{array}$ & $\begin{array}{l}\text { July } \\
2014\end{array}$ & $\begin{array}{c}\text { August } \\
2015\end{array}$ & $\begin{array}{c}\text { March } \\
2016\end{array}$ & $\begin{array}{c}\text { August } \\
2015\end{array}$ \\
\hline Expected Maturity (years) & 13 & 8 & 8 & 6.5 & 6.5 & 9 \\
\hline Yield & $4.80 \%$ & $4.59 \%$ & $4.32 \%$ & $4.42 \%$ & $6.25 \%$ & $4.50 \%$ \\
\hline $\begin{array}{l}\text { Value of issuances } \\
\text { (in USD millions) }\end{array}$ & 54.4 & 70.2 & 201.5 & 123.5 & 49.6 & 111 \\
\hline $\begin{array}{l}\text { Net present value of the } \\
\text { contracted solar cash } \\
\text { flows (in USD millions) }\end{array}$ & 87.8 & 106.2 & 276 & 182 & 76.4 & 146.5 \\
\hline Overcollateralization & $38 \%$ & $34 \%$ & $27 \%$ & $32 \%$ & $35 \%$ & $24 \%$ \\
\hline
\end{tabular}

S o u r c e : own work based on: 0'Sullivan \& Warren, 2016, p. 16; www3.

In 2013-2016, SolarCity implemented 5 securitization processes based on the lease of photovoltaic installations. The first funding programme, which initiated new class of assets subject to securitization process, was conducted in 2013, and brought USD 54.4 million of debt capital bearing annually interest of $4.8 \%$. Liability servicing against investors was based on cash flows generated by photovoltaic installations, which were provided and financed through leasing. Moreover, in order to reduce the risk of harmful interference with liability servicing, overcollateralization of $38 \%$ issue value was adopted (table 1). Subsequent securitization processes performed by SolarCity in principle corresponded to the same structure. Nevertheless, there can be observed a reduction in debt maturity date - the first securitization programme required instruments with maturity date up to 13 years, while in the case of other instruments, the maturity date was 8 and 6.5 years. 
In 2015, Sunrun, the second largest operator on the U.S. solar energy market, made its debut on the lease securitization market of photovoltaic installation. The parameters of the securitization carried out by the company, in principle, do not differ from the standard adopted by SolarCity. Sunrun carried out a securitization program, under which instruments with a total value of USD 111 million and an interest rate of $4.5 \%$ were issued. Furthermore, the same form of collateral in transaction (overcollateralization $=24 \%$ ) was used, and the issued instruments were granted the characteristics of long-term debt securities with maturity date up to 9 years. It is worth mentioning that the last characteristic, i.e. long-term nature of instruments issued within the analysed securitization processes, justifies the trend of a significant increase in the value of the market in question (figure 3).

\section{CONCLUSION}

Securitization of solar energy is a new and dynamically developing segment of the American financial market. The short history of securitization based on a new asset class makes it impossible to formulate unambiguous assessments regarding future development perspectives of this mechanism. Nevertheless, previous experience leads to the conclusion that the securitization mechanism can play an important role in supporting the dynamically developing solar energy market. The realization of long-term financial assets (represented by concluding leasing agreements) provides an initiator of securitization with a chance to extend the scale of operations and diversify sources of financing, as well as allows lowering the cost of capital and transferring risk associated with securitized assets.

In this respect, it should be noted that the potential prerequisite for the development of securitization market, which is based on a lease of photovoltaic installations, is its strong connotation with the concept of sustainable development. It is an important factor for both investors, especially those for whom the concept of socially responsible investment is dominant when undertaking activities, and issuers, who due to the risk of financing pro-ecological activities, may face difficulties in raising capital for the development of their operations (in this case, tailoring the offer of securitised financial instruments to investors implementing the concept of socially responsible investment may be a chance to gather hitherto unavailable funds). 
Despite the undisputed advantages and potential benefits of lease securitization of photovoltaic installations, attention should be paid to the foundations for further development of the market for these transactions. Based on the analyzed market history, it can be concluded that the performed transactions were occasional, and the value of the lease securitization market of photovoltaic installations was essentially built up by one issuer. Therefore, this leads to the question about the basis for the sustainable development of the market of these transactions.

Particular attention should also be given to another problem regarding various risk categories connected to securitization transactions of photovoltaic installation lease. These include risk associated with varying weather conditions (determining the efficiency of solar energy systems), risk of changes in prices of electricity generated from traditional fossil fuels (shaping energy consumption patterns), and political risk (affecting the conditions and law regulating the solar energy market). Although distinguishing these types of risks is of particular importance, it does not help in solving this problem.

\section{REFERENCES}

Alafita, T., \& Pearce, J.M. (2014). Securitization of residential solar photovoltaic assets: Costs, risks and uncertainty. Energy Policy, 67, 488-498. http://dx.doi.org/10.1016/j. enpol.2013.12.045.

Bartos, J.M. (2006). United States Law: A Practical Guide. Alphen aan den Rijn: Kluwer Law International.

Blommestein, H.J., Keshinler, A., \& Lucas, C. (2011). Outlook for the Securitization Market. OECD Journal: Financial Market Trends, 2011/1. http://dx.doi.org/10.1787/fmt2011-5kg55qw0jzf5.

Buchanan, B.G. (2017). Securitization and the Global Economy. History and Prospects for the Future. New York: Palgrave Macmillan.

Buszko, M., \& Krupa, D. (2016). Fundusze sekurytyzacyjne a zrównoważony rozwój rynku finansowego w Polsce. (Securitisation funds and sustainable development of financial market in Poland.) Prace Naukowe Uniwersytetu Ekonomicznego we Wrocławiu, 437, 75-86. http://dx.doi.org/ 10.15611/pn.2016.437.07.

Comello, S., \& Reichelstein, S. (2015). The Federal Investment Tax Credit for Solar Energy: Assesing and Addressing the Impact of the 2017 Step-Down. Renewable \& Sustainable Energy Reviews, 55, 591-602.

Davidson, A., Sanders, A., Wolff, L.L., \& Ching, A. (2003). Securitization. Structuring and Investment Analysis. Hoboken: Wiley \& Sons, Inc.

Deku, S.Y., \& Kara, A. (2017). Securitization: Past, Present and Future. Cham: Palgrave Macmillan. 
Fabozzi, F.J., \& Kothari, V. (2008). Introduction to Securitization. Hoboken: John Wiley \& Sons, Inc.

Fu, R., Feldman, D., Margolis, R., Woodhouse, M., \& Ardani, K. (2017). U.S. Solar Photovoltaic System Cost Benchmark: Q1 2017. Denver West Parkway: National Renewable Energy Laboratory.

Jacoby, S. (2013). Solar-Backed Securities: Opportunities, Risks, and the Specter of the Subprime Crisis. University of Pennsylvania Law Review, 162, 203-240.

Kothari, V. (2006). Securitization. The Financial Instrument of the Future. Singapore: J. Wiley and Sons (Asia) Pte Ltd.

Mrzygłód, U. (2012). Międzynarodowy kryzys finansowy - konsekwencje dla otoczenia regulacyjnego oraz procesów integracyjnych na rynkach finansowych Unii Europejskiej. (International Financial Crisis - Implications for Regulatory Environment and Financial Markets Integration in the European Union.) Ekonomia i Prawo, 10(3) part 4, 31-45.

O’Sullivan, F.M., \& Warren, C.H. (2016). Solar Securitization: In Innovation in Renewable Energy Finance. MIT Energy Initiative Working Paper, July, Cambridge.

Paligorova, T. (2009). Agency Conflicts in the Process of Securitization. Bank of Canada Review, 2009(Autumn), 33-47.

Półtorak, B. (2005). Sekurytyzacja kredytu hipotecznego. (Securitization of Mortgage Loan.) Warszawa: CeDeWu.

Póltorak, B. (2017). Sekurytyzacja jako instrument optymalizacji podatku bankowego (The Bank Tax Optimization by Securitisation). In I.D. Czechowska, S. Wieteska (Eds.). Granice finansów XXI wieku. Bankowość i ubezpieczenia. (The limits of finance in the 21st century. Banking and insurance.) Łódź: Wydawnictwo Uniwersytetu Łódzkiego. http://dx.doi.org/10.18778/8088-791-6.06.

Raczkowska, I.A. (2001). Sekurytyzacja wierzytelności bankowych. (Securitization of Bank Claims.) Warszawa: Wydawnictwo Konieczny i Kruszewski.

Reksa, Ł. (2007). Sekurytyzacja w krajach Unii Europejskiej oraz w polskim systemie bankowym. (Securitization in European Union Countries and in the Polish Banking System.) Warszawa: Generalny Inspektorat Nadzoru Bankowego.

Schwarcz, S.L. (2010). The Future of Securitization. In R.W. Kolb (Ed.). Lessons from Financial Crisis. Causes, Consequences, and Our Economic Future. Hoboken: John Wiley and Sons, Inc.

Waszkiewicz, A. (2011). Ryzyko sekurytyzacji a kryzys finansowy. (Securitization Risk and the Financial Crisis.) Warszawa: Oficyna Wydawnicza Szkoły Głównej Handlowej w Warszawie.

(www1) Greentech Media, http://www.greentechmedia.com (accessed: 30.05.2018).

(www2) SIFMA, http://www.sifma.org (accessed: 30.05.2018).

(www3) Tesla: Investors Overview, http://ir.tesla.com (accessed: 2.06.2018).

(www4) EUR-Lex, http://www.eur-lex.europa.eu (accessed: 27.09.2018). 